ARTICLES

Submitted 05.07.2014. Approved 12.17.2014

Evaluated by double blind review process. Scientific Editor: Rodrigo Bandeira-de-Mello

DOI: http://dx.doi.org/10.1590/So034-759020150409

\title{
STRATEGIC DECISIONS OF FAMILY FIRMS ON CASH ACCUMULATION
}

\author{
Decisões estratégicas de empresas familiares sobre acúmulo de dinheiro \\ Decisiones estratégicas de empresas familiares sobre acumulación de efectivo
}

\begin{abstract}
Given the particular strengths, weaknesses, and peculiarities of family firms as well as the importance of liquidity in today's marketplace, we analyze the distinct characteristics and strategies of family businesses related to the amount of cash a firm holds. We look beyond the traditional factors that influence decisions related to cash management to examine factors that are particularly important for family firms. Specifically, we outline the relevance of strategic decisions guided by family firms' conservatism, flexibility, long-term view, and the active control that they have over family members. To our knowledge, no prior studies exist regarding family firms and their strategic adjustment of cash holding. Therefore, we investigate whether the ownership structure of the firm (through the presence of a controlling family) moderates decisions on cash holding. We found that family firms tend to accumulate cash for strategic reasons and as a result of their own idiosyncrasies. Thus, family firms can achieve optimal cash accumulation more efficiently than non-family firms.
\end{abstract}

KEYWORDS | Family firms, ownership, cash, liquidity, family control.

\section{RESUMO}

Dadas as forças, fraquezas e peculiaridades das empresas familiares, bem como a importância da liquidez no Mercado atual, foram analisadas as diferentes características e estratégias de negócios familiares com relação à quantidade de caixa que uma empresa mantém. Neste artigo, olha-se além dos fatores tradicionais que influenciam decisões relacionadas ao gerenciamento de caixa, a fim de examinar os fatores particularmente importantes para empresas familiares. Especificamente, foi delineada a relevância de decisões estratégicas guiadas pelo conservadorismo, flexibilidade e visão de longo prazo das empresas familiares, bem como do controle que exercem sobre os membros da família. Até onde sabemos, não existem estudos prévios com relação a empresas familiares e seus ajustes estratégicos de montante em caixa. Portanto, investigou-se a estrutura de propriedade da firma (através da presença de uma família controladora) possui efeito moderador sobre as decisões relativas ao montante em caixa. Conclui-se que empresas familiares tendem a acumular caixa por razões estratégicas, e também como resultado de suas próprias idiossincrasias. Assim, empresas familiares podem atingir acúmulo ótimo de caixa mais eficientemente do que empresas não familiares.

PALAVRAS-CHAVE I Empresas familiares, propriedade, caixa, liquidez, controle familiar.

\section{RESUMEN}

Dadas las particulares fuerzas, flaquezas, y peculiaridades de las empresas familiares así como la importancia de la liquidez en el mercado hoy en día, analisamos las características y estrategias distintas de negocios familiares en relación a la cantidad de efectivo que una empresa mantiene. Miramos más allá de los factores tradicionales que influencian las decisiones relacionadas a la gestión financiera para examinar factores que son particularmente importantes para las empresas familiares. Más especificamente, esbozamos la relevancia de decisiones estratégicas guiadas por el conservadurismo, la flexibilidad, visión a largo plazo de la empresa familiar, y el control activo que eso ejerce sobre los miembros de la familia. De acuerdo con nuestros conocimientos no existen estudios anteriores relacionados a empresas familiares y su ajuste de retención de efectivo. Por lo tanto, investigamos si la estructura de propiedad de la empresa (a través de la presencia de una familia dirigente) modera decisiones relativas a retención de efectivo. Descubrimos que empresas familiares tienden a acumular efectivo por razones estratégicas y como resultado de sus propias idiosincrasias. De este modo, empresas familiares pueden alcanzar óptimas acumulaciones de efectivo más eficientemente que empresas no familiares.

\author{
Professor at Universidad de \\ Salamanca, Departamento de \\ Administración y Economía de la \\ Empresa - Salamanca, Spain
}

PALABRAS-CLAVE I Empresas familiares, propiedad, efectivo, liquidez, control familiar. 


\section{WHY STUDY THE CASH DECISIONS OF FAMILY FIRMS?}

After a period of easy access to capital, the economic crisis caused firms to rethink their cash-holding strategy, with firms becoming more committed to holding a suitable amount of cash. Following the credit crunch associated with the economic crisis, firms, if possible, accumulate cash to prepare for unforeseen circumstances. Brush (2008) argues that one of the three main strategies that successful entrepreneurs must employ to start and grow a business is managing cash for bootstrapping, that is, conserving financial resources and using cash resourcefully. This topic has only recently attracted interest in the literature. Although corporate liquidity is an important strategic decision, research into the consequences of accumulating cash has been to a greater or lesser extent absent from the traditional literature. Cash management is a strategic decision that encompasses the whole spectrum of business activities, from long-run strategic planning to day-today operations (Chastain, 1986). In fact, cash decisions impinge on firms' investment decisions and are affected by the existence of market imperfections such as information asymmetry, financial distress, and agency conflicts.

Although cash management is clearly important to organizations of any size and nature, these strategic decisions are even more significant when the organization is family run. Family control is a particularly interesting type of ownership structure, and much has been written about it theoretically and empirically in an attempt to identify the characteristics of family firms (Kidwell, Eddleston, Cater, \& Kellermanns, 2013). Family owners are the predominant type of controlling shareholders in many developing countries and in some of the world's most developed economies. In fact, family control is found in many geographical regions and within different legal and financial systems, including the United States, Western Europe, and East Asia (see, e.g., Anderson \& Reeb, 2003; Franks \& Mayer, 2001; Gadhoum, Lang, \& Young, 2005; Lee, 2006).

To our knowledge, no previous studies exist about family firms and their liquidity decisions. Therefore, we analyse the way in which family behaviour motivates the strategic adjustment of cash holding. That is, we analyse whether the ownership structure of a family firm moderates the determinants of its cash holding. More precisely, we attempt to disentangle whether the presence of a controlling family in the company mitigates or exacerbates the accumulation of cash.

Given this objective, we first define a family business because no consensus exists in the literature on the criteria to classify companies as family or non-family firms. Although prior research focuses on various criteria (e.g., ownership, manage- ment and ownership, involvement of the family, etc.), the most important literature refers to publicly traded family-controlled firms. La Porta, Lopez-de-Silanes, and Shleifer (1999) argue that families that hold the majority of shares of a company also tend to participate in management. Public firms (family and non-family controlled) are usually large with a prior trajectory and good possibilities of resorting to capital markets for funding. This profile of family-controlled firms comprises listed firms in which the majority of the ownership is a family, although it also includes non-family shareholders and minority shareholders. Given this discussion, we do not take into account either very young family firms or firms with $100 \%$ family ownership (closely held firms).

The remainder of the paper is organized as follows. Section 2 briefly describes the main factors that affect cash accumulation. Section 3 posits the way in which family firms undertake this decision. Finally, Section 4 offers our conclusions on the tendency of family firms to accumulate cash.

\section{FAMILY FIRMS AND CASH ACCUMULATION: WHY DO FAMILY FIRMS ACCUMULATE CASH DIFFERENTLY?}

All companies, regardless of their ownership structure, maintain a specific level of cash in their assets. Firms primarily accumulate cash to meet daily operating needs. Holding cash is thus based on a precautionary motive: Firms must have the appropriate amount of resources to invest in profitable projects and to ensure the ongoing operations of the firm.

Several other factors also affect cash accumulation, such as substitute liquid assets, cash flow volatility, leverage, investment opportunities, and size. Thus, accumulated cash first depends (using cash flow generated and size as the usual control variables) on the firm's decision to hold liquid assets - instead of, or in addition to, cash - or to have available credit lines (Hardin, Highfield, Hill, \& Kelly, 2009). Cash flow volatility is also a relevant factor because it can cause firms to maintain higher cash levels to take advantage of the profits from new investment opportunities (Kim, Mauer, \& Sherman, 1998). Finally, debt level can affect cash levels; however, the literature is mixed on just how these two factors interact. In the context of family firms, other reasons can help to identify family firms' differential behaviour when making strategic decisions relating to liquidity. In fact, important differences exist between family and non-family firms with regard to intangible family assets, such as dedication and family effort. The literature also reflects differences related to profitability, capital structure, 
management, diversification, and size, although the evidence on differences in strategic management between family and non-family firms is not conclusive. Evidence also suggests that family-controlled firms outperform non-family firms around the world (Ali, Chen, \& Radhakrishnan, 2007; Anderson \& Reeb, 2003; Barontini \& Caprio, 2006; Maury, 2006, among others), although research on this topic is mixed (Barth, Gulbrandsen, \& Schønea, 2005; Demsetz \& Villalonga, 2001; Miller, Breton-Miller, Lester, \& Cannella, 2007; Villalonga \& Amit, 2006, among others). Certainly, however, family-controlled firms are different from non-family firms in terms of goals, vision, and culture (Arrègle, Hitt, Sirmon, \& Véry, 2007; Chua, Chrisman, \& Sharma, 1999; Gomez-Mejia, Nunez-Nickel, \& Gutierrez, 2001; Gomez-Mejia, Takács, Nuñez-Nickel, Jacobson, \& Moyano-Fuentes, 2007, among others).

The strategies of family firms also appear to be different from their non-family counterparts (Patel, Pieper, \& Hair, 2012). A recent strand of literature focuses on the behaviour of individuals and how this behaviour can affect a firm's decisions. For example, prior research argues that family-controlled firms are risk averse (La Porta et al., 1999), mainly because they have an undiversified ownership position (Morck \& Yeung, 2003). However, Gomez-Mejia et al. (2007) state that family-controlled firms are not risk averse but rather loss averse. These authors introduce the concept of socio-emotional wealth, which refers to a firm's non-financial aspects that meet the family's affective needs, such as identity, the ability to exercise family influence, and the perpetuation of the family dynasty. The family is concerned with this socio-emotional wealth, and therefore they act to avoid losing it.

\section{STRATEGIC DECISION-MAKING IN CASH HOLDING}

We analyse the differences between how family and non-family firms make use of cash. Family firms are more likely to target cash accumulation not only because of the benefits associated with cash accumulation but also for other reasons directly related to the nature of the family firm, including its ownership structure.

Logically, family firms should tend to hoard higher levels of cash, but some additional reasons may help to explain this decision. To begin, almost by definition, family firms are highly conservative: their decisions are focused on increasing control and keeping the firm in operation as many years as possible and for as many generations of the family as possible, (Burkart, Panunzi, \& Shleifer, 2003; Gomez-Mejia et al., 2007; Morck \& Yeung, 2003). Miller, Le Breton-Miller, and Lester (2011) found that firms in which the family is the largest shareholder are more prone than other firms to pursue conservative strategies. Cash is the most conservative means of payment, and it therefore takes on special relevance in regard to the firm's strategic decisions. Family-controlled firms have longer investment horizons (Miller et al., 2011; Pindado, Requejo, \& Torre, 2011), and therefore the family will likely act for the benefit of the firm most of the time. One way of maintaining this long-term perspective is by controlling the decision on cash holding so that the firm attains an objective cash ratio. The family tries to maintain a high enough level of available cash to undertake investments when necessary (Dittmar \& Duchin, 2012).

Family firms' flexibility in the decision-making process is an important factor that can influence a firm's ability to adjust its cash holding, especially because these firms have certain advantages related to being family owned, such as the dedication of the family, commitment to the company, and interaction between ownership and management. Family firms can easily adapt to changes in the environment by adjusting strategies to specific situations that may arise. Decisions on cash holding constitute a strategic decision for family firms because cash availability provides flexibility. In this way, family firms obtain a competitive advantage, having the ability to invest in resources that create added value to the organization. Flexibility allows them to compete with other firms in an uncertain environment, continually anticipate the environment, and have a great capacity for reacting in time. In addition, maintaining greater financial flexibility allows a firm to make important decisions, such as undertaking projects without having to resort to capital markets and reducing the costs of the information asymmetry between investors and managers.

Because the families act simultaneously as shareholder and manager, family firms can better predict possible future shocks to the cash flow (Ali et al., 2007) and therefore can also better predict the optimal level of cash holding. Furthermore, family-controlled firms see cash holdings as a way to accumulate wealth and to avoid possible tax costs of taking the money out of the firm (Dittmar, Mahrt-Smith, \& Servaes, 2003).

Accumulating cash has high potential costs because the firm may lose investment opportunities. However, if external financing is costly, firms have the incentive to hoard cash holdings to avoid the possible adverse consequences associated with sales shocks or investment opportunities (Denis, 2011). In addition, when we consider family-controlled firms, financial constraint is not only due to external factors but may also depend on the strategic behaviour of families. Family-controlled firms are reluctant to obtain outside financing at the same pace as non-family firms (Barontini \& Caprio, 2006; Faccio \& Lang, 2002). In his study of external funding, Andres (2009) argues that family firms think of debt as a potential hazard due to the increase in the probability of default. He suggests that family firms may avoid new 
share offerings because this action involves a reduction in the family control over the company. Consequently, cash holdings can serve as a hedge mechanism that family firms use to avoid any possible bankruptcy risk and to ensure that most valuable investments are undertaken.

According to the free cash flow theory (Jensen, 1986), the availability of funds at the disposal of the manager can lead to investments in non-profitable projects, acquisitions of industries familiar to the manager, and spending on perquisites that favour the manager and not the firm (i.e., overinvestment or expropriation). Liquidity thus has high potential costs because it facilitates conflict by inducing organizational inefficiencies that destroy shareholder wealth (Harford, 1999). However, when considering this shareholder-manager conflict, family-controlled firms lack the typical agency problem between shareholders (principal) and managers (agent). As previously discussed, the family as the major shareholder is also present in management, which aligns the objectives of both to the benefit of the family (Ali et al., 2007; Villalonga \& Amit, 2006). Following this reasoning, in principle, we assume that cash holding in these firms do not lead to high agency costs.

Nevertheless, family-controlled firms are not without agency issues. Given their ownership structure, the family is likely to use different mechanisms to increase its control over the firm (Barontini \& Caprio, 2006; Faccio \& Lang, 2002; Faccio, Lang, \& Young, 2001; Maury, 2006, among others). Sometimes these mechanisms enhance control rights over cash flow rights, and non-family shareholders may worry about possible expropriation from the controlling family owners (La Porta et al., 1999). In this scenario, the family may be tempted to extract private benefits from minority shareholders. Therefore, due to the problem of possible expropriation, all else being equal, family firms will likely hoard higher levels of cash to pursue family benefits to the detriment of minority shareholder value (e.g., minimizing the dividend policy in favour of accumulating cash).

The discussion thus far suggests that the family effect on the cash holding policy depends on whether the effect of owner-manager alignment on the one hand outweighs the effect of the potential agency problem between majority and minority shareholders on the other hand. If so, family-controlled firms will hold more cash than non-family firms. Thus, family-controlled firms are reluctant to obtain outside financing at the same pace as non-family firms (Barontini \& Caprio, 2006; Blanco-Mazagatos, Quevedo-Puente, \& Castrillo, 2007; Faccio \& Lang, 2002; Gomez-Mejia et al., 2007, among others), and they will avoid monitoring mainly to maintain control.

Finally, the implications for cash holdings will likely depend on the legal and institutional framework to which the firms belong.
Several cross-country studies analyse the institutional framework and its influence on cash holdings, focusing on large firms listed on the financial markets (Dittmar et al., 2003; Ferreira \& Vilela, 2004; Guney, Ozkan, \& Ozkan, 2003; Kalcheva \& Lins, 2007; Ozkan \& Ozkan, 2004; Pinkowitz, Stulz, \& Williamson, 2003, 2006). Kusnadi and Wei (2011) find evidence that the legal protection of investors represents a first-order effect in influencing international firms' cash policy. The literature in general agrees that the lower the protection, the larger the cash holding. Common law countries offer greater shareholder protection, which encourages market development (Djankov, La Porta, Lopez-de-Silanes, \& Shleifer, 2008). In addition, firms in common law countries have easier access to external capital markets, and, consequently, are expected to be less aggressive in their cash holdings (Faulkender \& Wang, 2006; Kusnadi \& Wei, 2011). In contrast, companies in countries with low shareholder protection hold on to more of their cash. In the continental model, where the investors are less protected, more cash is likely accumulated due to the need for flexibility, and the system is more inefficient because the investor is not sufficiently protected. Along this line, Drobetz and Grüninger (2007) argue that median-sized Swiss firms hold nearly twice the cash and equivalents of median-sized US or UK firms.

Thus, the level of investor protection of a country plays a moderating role between the relation of family control and the firm's cash holding. In countries with strong investor protection, the cash accumulation of family firms is less affected by the institutional effect, and in countries with weak legal protection, cash holding in family firms can be particularly beneficial.

In sum, Figure 1 shows that cash holding in family firms is determined by the institutional framework and, apart from the traditional variables, strategic reasons and motives that are idiosyncratic to the unique characteristics of family firms, including conservative strategies, flexibility, financial constraints, and the trade-off between agency costs.

\section{Figure 1. Cash holdings in family firms}

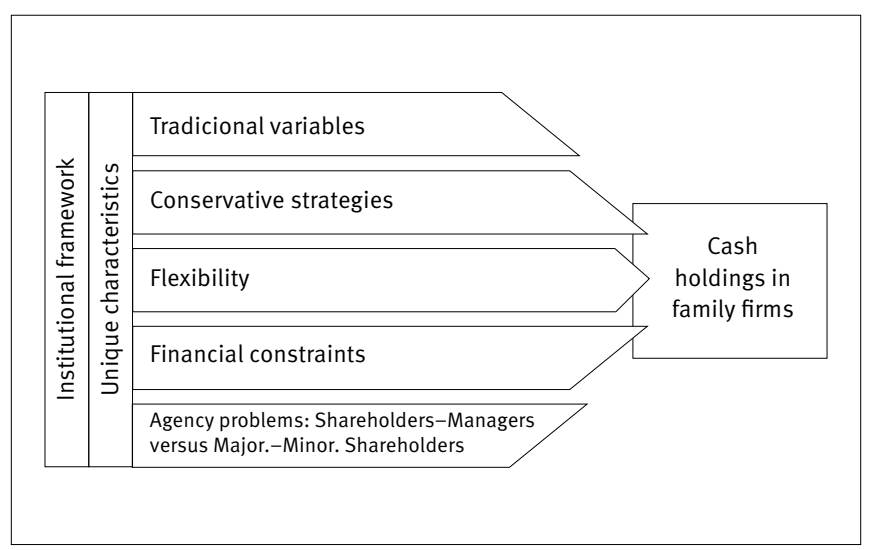




\section{CONCLUSION}

A firm's ownership structure is vitally important to firms when determining their strategy related to cash holdings. Considering the unique characteristics of family firms, in principle we assume that a difference exists in the way that family and non-family firms approach cash holding. This issue is of particular interest because (a) prior research does not address the role of families in corporate cash holding decisions and (b) controversy remains concerning the advantages and disadvantages attributable to family control relative to other types of organizational forms.

In addition to identifying the main variables that affect the cash decision in firms, we show that family firms possess certain characteristics that affect their strategic decision-making. This issue, which is of particular interest due to its relevancy in the recent economy, especially in the family firm context, allows to highlight the advantages and disadvantages attributable to family control relative to other types of organizational forms.

The task of choosing the optimal level of cash holdings differs depending on firms' needs, structure, strategy, and future prospects. Family-controlled firms must balance the benefits and costs of cash holdings while considering what effect these family firm-specific characteristics and preferences will have on the family.

Family firms' conservativism, flexibility, long-term perspective, and active family control are factors that contribute to make cash holding decisions particularly important. Thus, for instance, when the decision arises whether to hold onto cash for precautionary reasons or to employ it in new investments of uncertain reliability, family firms will likely choose a conservative strategy and retain the cash.

In addition, the effect of the family depends on the tradeoff between the agency problem between majority and minority shareholders on the one hand and the alignment of incentives between shareholders and managers on the other. In addition, family firms resist external funding due to high transaction costs and increased monitoring, which managers and family-controlled firms wish to avoid to retain more control.

We analyse whether this kind of behaviour motivates a strategic adjustment in family firms' cash holding. We affirm that cash holding decisions are moderated by the ownership structure of the firm and that the presence of a controlling family in the company exacerbates the accumulation of cash due to the special characteristics associated with family firms. However, no extreme is good. That is, firms should avoid excess cash accumulation not only for the previously discussed reasons (e.g., the high opportunity cost of cash if it lies idle) but also because some of the unique characteristics of family firms that are in principle beneficial to firm value can become problematic if the level of cash is too high. In this case, firms may be prone to bad decision-making if they have too much cash on hand.

We also point out some limitations and precautions that family firms should take into account when making decisions related to cash accumulation. First, family firms should not abuse their strengths; rather, they should be cautious in their decision-making and avoid becoming overconfident and overly conservative. For example, an excess of conservativism can lead them to resort too infrequently and inadequately to the markets. This attitude can weaken firms in the long run and may lead them to accumulate cash reserves that can postpone growth. Second, although family-controlled firms can reduce or even eliminate the agency problem between owners and managers, they are also able to extract private benefits from minority shareholders.

We show that, beyond the traditional factors, family firms tend to accumulate cash for strategic reasons based on their unique characteristics as family-owned firms, including conservative strategies, flexibility, financial constraints, and the trade-off between agency costs. The institutional framework also affects family firms' cash holding decision-making. Given this outline, we hope that this theoretical perspective provides justification for further study in this matter and that it contributes to the empirical development of the literature on family firms and cash holding.

\section{REFERENCES}

Ali, A., Chen, T. Y., \& Radhakrishnan, S. (2007). Corporate disclosures by family firms. Journal of Accounting and Economics, 44(1-2), 238-286. doi:10.1016/j.jaccec0.2007.01.006

Anderson, R. C., \& Reeb, D. M. (2003). Founding-family ownership and firm performance: Evidence from the S\&P 500. Journal of Finance, 58(3), 1301-1327. doi: 10.1111/1540-6261.00567

Andres, C. (2009). Family ownership, financing constraints and investment decisions [Working Paper]. SSRN.

Arrègle, J.-L., Hitt M. A., Sirmon D. G., \& Véry, P. (2007). The development of organizational social capital: Attributes of family firms. Journal Management Studies, 44(1), 73-95. doi:10.1111/j.1467-6486.2007.00665.X

Barontini, R., \& Caprio, L. (2006). The effect of family control on firm value and performance: Evidence from Continental Europe. European Financial Management, 12(5), 689-723. doi:10.1111/j.1468036x.2006.00273.X

Barth, E., Gulbrandsen, T., \& Schønea, P. (2005). Family ownership and productivity: The role of owner-management. Journal of Corporate Finance, 11(1-2), 107-127. doi:10.1016/j.jcorpfin.2004.02.001

Blanco-Mazagatos, V., Quevedo-Puente, E., \& Castrillo, L. A. (2007). The trade-off between financial resources and agency costs in the family business: An exploratory study. Family Business Review, 20(3), 199213. doi:10.1111/j.1741-6248.2007.00095.x

Brush, C. G. (2008). Pioneering strategies for entrepreneurial success. Business Horizons, 51(1), 21-27. doi:10.1016/j.bushor.2007.09.001 
Burkart, M., Panunzi, F., \& Shleifer, A. (2003). Family firms. The Journal of Finance, 58(5), 2167-2202. doi:10.1111/1540-6261.00601

Chastain, C. E. (1986). Integration of cash management. Business Horizons, 29(6), 79-84. doi:10.1016/0007-6813(86)90042-x

Chua, J., Chrisman, J., \& Sharma, P. (1999). Defining the family business by behavior. Entrepreneurship Theory and Practice, 23(4), 19-39.

Demsetz, H., \& Villalonga, B. (2001). Ownership structure and corporate performance. Journal of Corporate Finance, 7(3), 209-233. doi:10.1016/ Sog29-1199(01)00020-7

Denis, D. J. (2011). Financial flexibility and corporate liquidity. Journal of Corporate Finance, 17(3), 667-674. doi:10.1016/j.jcorpfin.2011.03.006

Djankov, S., Porta, R. La, Lopez-de-Silanes, F., \& Shleifer, A. (2008). The law and economics of self-dealing. Journal of Financial Economics, 88(3), 430-465. doi:10.1016/j.jfinec0.2007.02.007

Dittmar, A., \& Duchin, R. (2012). The dynamics of cash [Working Paper 1138]. Ross School of Business.

Dittmar, A., Mahrt-Smith, J., \& Servaes, H. (2003). International corporate governance and corporate cash holdings. Journal of Financial and Quantitative Analysis, 38(1), 111-133. doi:10.2307/4126766

Drobetz, W., \& Grüninger, M. C. (2007). Corporate cash holdings: Evidence from Switzerland. Financial Markets Portfolio Management, 21(3), 293-324. doi:10.1007/s11408-007-0052-8

Faccio, M., \& Lang, L. H. P. (2002). The ultimate ownership of Western European corporations. Journal of Financial Economics, 65(3), 365-395. doi:10.1016/S0304-405X(02)00146-0

Faccio, M., Lang, L. H. P., \& Young, L. (2001). Dividends and expropriation. American Economic Review, 91(1), 54-78.

Faulkender, M., \& Wang, R. (2006). Corporate financial policy and the value of cash. Journal of Finance, 61(4), 1957-1990. doi:10.1111/j.1540$6261.2006 .00894 . x$

Ferreira, M. A., \& Vilela, A. (2004). Why do firms hold cash? Evidence from EMU countries. European Finance Management, 10(2), 295-319. doi:10.1111/j.1354-7798.2004.00251.x

Franks, J. R., \& Mayer, C. (2001). Ownership and control of German corporations. Review of Financial Studies, 14(4), 943-977.

Gadhoum, Y., Lang, L. H. P., \& Young, L. (2005). Who controls US? European Financial Management, 11(3), 339-363. doi:10.1111/j.13547798.2005.00287.x

Gomez-Mejia, L. R., Nunez-Nickel, M., \& Gutierrez, I. (2001). The role of family ties in agency contracts. Academy of Management Journal, 44(1), 81-95.

Gomez-Mejia, L., Takács, K., Nuñez-Nickel, M., Jacobson, K., \& Moyano-Fuentes, J. (2007). Socioemotional wealth and business risks in family-controlled firms: Evidence from Spanish olive oil mills. Administrative Science Quarterly, 52(1), 106-137. doi:10.2189/asqu.52.1.106

Guney, Y., Ozkan, A., \& Ozkan, N. (2003). Additional international evidence on corporate cash holding [Working Paper]. SSRN.

Hardin, W. G., III, Highfield, M. J., Hill, M. D., \& Kelly, G. W. (2009). The determinants of REIT cash holdings. Journal of Real Estate Finance and Economics, 39(1), 39-57. doi:10.1007/s11146-007-9103-1

Harford, J. (1999). Corporate cash reserves and acquisitions. The Journal of Finance, 54(6), 1969-1997.
Jensen, M. C. (1986). Agency costs of free cash flow, corporate finance, and takeovers. American Economic Review, 76(2), 323-329.

Kalcheva, I., \& Lins, K. (2007). International evidence on cash holdings and expected managerial agency problems. Review of Financial Studies, 20(4), 1087-1112. doi:10.1093/rfs/hhmo23

Kidwell, R. E., Eddleston, K. A., Cater, J. J., III, \& Kellermanns, F. W. (2013). How one bad family member can undermine a family firm: Preventing the Fredo effect. Business Horizons, 56(1), 5-12. doi:10.1016/j.bushor.2012.08.004

Kim, CH-S., Mauer, D., \& Sherman, A. (1998). The determinants of corporate liquidity: Theory and evidence. Journal of Financial and Quantitative Analysis, 33(3), 335-359. doi:10.2307/2331099

Kusnadi, Y., \& Wei, K. C. J. (2011). The determinants of corporate cash management policies: Evidence from around the world. Journal of Corporate Finance, 17(3), 725-740. doi:10.1016/j.jcorpfin.2010.12.002

La Porta, R., Lopez-de-Silanes, F. La, \& Shleifer, A. (1999). Corporate ownership around the world. The Journal of Finance, 54(2), 471-517. doi:10.1111/0022-1082.00115

Lee, J. (2006). Family firm performance: Further evidence. Family Business Review, 19(2), 103-114. doi:10.1111/j.1741-6248.2006.00060.x

Maury, B. (2006). Family ownership and firm performance: Empirical evidence from Western European corporations. Journal of Corporate Finance, 12(2), 321-341. doi:10.1016/j.jcorpfin.2005.02.002

Miller, D., Le Bretton-Miller, I. \& Lester, R. (2011). Family and lone founder ownership and strategic behavior: Social context, identity and institutional logics. Journal of Management Studies, 48(1), 1-25. doi:10.1111/ j.1467-6486.2009.00896.x

Miller, D., Le Breton-Miller, I., Lester, R. H., \& Cannella, A. A. (2007). Are family firms really superior performers? Journal of Corporate Finance, 13(5), 829-858. doi:10.1016/j.jcorpfin.2007.03.004

Morck, R., \& Yeung, B. (2003). Agency problems in large family business groups. Entrepreneurship Theory and Practice, 27(4), 367-382. doi:10.1111/1540-8520.to1-1-00015

Ozkan, A., \& Ozkan, N. (2004). Corporate cash holdings: An empirical investigation of UK companies. Journal of Banking and Finance, 28(9), 2103-2134. doi:10.1016/j.jbankfin.2003.08.003

Patel, V. K., Pieper, T. M., \& Hair, J. F., Jr. (2012). The global family business: Challenges and drivers for cross-border growth. Business Horizons, 55(3), 231-239. doi:10.1016/j.bushor.2012.01.002

Pindado, J., Requejo, I., \& Torre, CH. De La (2011). Family control and investment-cash flow sensitivity: Empirical evidence from the Euro zone. Journal of Corporate Finance, 17(5), 1389-1409. doi:10.1016/j.jcorpfin.2011.07.003

Pinkowitz, L., Stulz, R., \& Williamson, R. (2003). Do firms in countries with poor protection of investor rights hold more cash? [Working Paper]. SSRN.

Pinkowitz, L., Stulz, R., \& Williamson, R. (2006). Does the contribution of corporate cash holdings and dividends to firm value depend on governance? A cross-country analysis. Journal of Finance, 61(6), 2725-2751. doi: 10.1111/j.1540-6261.2006.01003.x

Villalonga, B., \& Amit, R. (2006). How do family ownership, control and management affect firm value? Journal of Financial Economics, 80(2), 385-417. doi:10.1016/j.jfineco.2004.12.005 